\title{
Effectiveness of Topical Chemotherapy in Pigmented and Squamous Lesions of the Ocular Surface: Literature Review
}

\author{
Alejandra Lozano Bustillo ${ }^{1^{*}}$, Mariel Eunice Amador-Rosa ${ }^{2}$ and Rocío Mitchell Banegas Erazo ${ }^{3}$ \\ ${ }^{1}$ Ophthalmology Specialist, National Autonomous University of Honduras (UNAH), Honduras \\ 2Ophthalmology Specialist 'Alliance Diagnostic Center', Honduras \\ ${ }^{3}$ Ophthalmology Resident, San Felipe General Hospital (UNAH), Honduras
}

*Corresponding author: Alejandra Lozano Bustillo, National Autonomous University of Honduras, Honduras, Tel: +50433695890

\begin{abstract}
Introduction: The standard of care for the treatment of ocular surface lesions seems to have changed from surgery to topical chemotherapeutic agents as supplements to it or even as sole therapy, despite the scarcity of long-term studies in the published literature.

Methods: A search in the academic search engines of PubMed, Google academic and Cochrene, of articles published in English language from the years 1997 to 2020 on chemotherapeutic management of ocular surface diseases.

Conclusion: Topical or perilesional chemotherapy as a single therapeutic agent has proven to be an effective treatment avoiding the risks of repeated surgical interventions. Larger controlled studies with longer follow-up periods are recommended to confirm the long-term efficacy and safety of these treatments.
\end{abstract}

\section{Keywords}

Chemotherapy, Topical, Mitomycin C, 5-fluorouracil, Interferon, Squamous neoplasia, Melanocytic lesions, Ocular surface

\section{Introduction}

Topical chemotherapy is becoming the preferred approach in treating ocular surface lesions, especially for diffuse, annular, or multifocal lesions which are difficult to manage surgically. Ocular surface neoplasms can present as a pigmented or non-pigmented lesion of the conjunctiva or cornea, usually near the limbus. Ocular surface squamous neoplasms (OSSN) can be diagnosed clinically by their gelatinous, papillary, or leukoplastic appearance. They often spread as a cell growth on the cornea. Pigmented or melanocytic lesions of the conjunctiva and cornea include nevi, primary acquired melanosis (PAM) with or without atypia and conjunctival melanoma.

Inadequate initial therapy is a major risk factor for recurrence. Treatment strategies are affected by tumor staging according to the American Joint Cancer Committee (AJCC) T-stage at presentation [1,2], so any suspicious lesion requires a histopathological diagnosis currently assisted by imaging studies such as anterior segment optical coherence tomography (AS-OCT) [3-5].

Current chemotherapeutic treatments in ophthalmology include Interferon alfa 2b (IFNa2b), 5-fluorouracil (5FU) and Mitomycin C (MMC) mainly. Many studies in other entities that have taken interest in recent years, such as the use of nucleases in dry eye or previous uveitic diseases, have been very popular with good and bad results [6-11]. The purpose of this review is to familiarize general ophthalmologists with ocular surface chemotherapy treatments, as well as to summarize the essential published literature on the use of agents for corneal and conjunctival neoplasms.

\section{Methods}

We review different articles in the relevant medical literature that describe the use of topical chemotherapy agents as a treatment for neoplastic melanocytic and 
non-melanocytic entities and OSSN.

A search was carried out in the academic search engines of PubMed, Academic Google and Cochrene, for articles published in English language from the years 1997 to 2020 on the diagnosis and management of ocular surface diseases. Only original articles, case reports, case series and scientific comments were included. Review articles, letters to the editor, and articles in a language other than English were excluded.

Search included the following keywords individually and in combination: chemotherapy, topical, mitomycin C, 5-fluorouracil, interferon, conjunctival neoplasia, conjunctival tumor, conjunctival nevi, primary acquired melanosis, conjunctival melanoma, squamous cell carcinoma, squamous surface ocular neoplasm and conjunctival papilloma.

\section{Interferon in ocular surface lesions}

Interferons (IFNs) are a group of glycoproteins that form a network of complex interactions with other cytokines and connect innate and adaptive immunity. They exhibit a variety of biological functions, including antiviral, anti-proliferative, immunomodulatory, and cytotoxic activities. It is currently the most studied molecule since it has been shown to be effective and safe as a treatment for primary or recurrent ocular surface lesions with minimal adverse effects, providing a less invasive approach $[12,13]$.

Currently, it is Interferon alpha $2 b$ (IFNa2b) that is frequently used in ophthalmology, and it appears to be as successful as cryotherapy and surgical excision, which are the traditional forms of treatment for suspicious ocular surface lesions $[14,15]$. It is used topically, subconjunctival and/or perilesional injection or in conjunction with surgery.

Topical IFNa2b avoids the risks of further destruction of limbal stem cells and damage from surgical excision and could even be cost-effective for patients [16]. If invasive disease is diagnosed at any stage, topical therapy is contraindicated and surgical excision is required $[18,19]$. An important mechanism of action of IFNa2b is the reduction of the viral load of human papillomavirus (HPV) in infected cells of the conjunctiva in the squamous epithelium (Kostkowski and Herman 2004). Patients with primary or recurrent OSSN or large papillomas treated topically or with subconjunctival injections of IFNa2b until tumor resolution have had excellent results with low recurrence rates and a median resolution of up to 1.4 months $[20,21]$. IFNa2b, when properly combined with surgical excision in OSSN, provides proliferative control of up to $95 \%$ of cases, reaching rates of $90 \%$ in tumors in situ, in $100 \%$ of T1, $100 \%$ of T2, $94 \%$ of T3 and in $100 \%$ of T4 tumors according to the AJCC classification [22].

Whether via subconjunctival/perilesional or topical,
IFNa2b in giant OSSN above $20 \mathrm{~mm}$ treated with subconjunctival injection achieved almost complete tumor control (immunotherapy) in most of the patients reported in Kim, et al. study and a partial tumor control with reduction in size (immunoreduction) which allows subsequent surgical excision. A combination of topical and injectable IFN 2 b completely resolved tumors larger than $30 \mathrm{~mm}$ during a period of up to 6 months in followup $[23,24]$.

Many forms of synergistic treatment combinations to enhance the effectiveness of IFNa2b in those patients with associated systemic conditions have been made $[25,26]$. An example in ocular surface is the use of topical interferon alpha 1 million IU/ml drops 4 times a day in combination with retinoic acid $0.01 \%$ once every two days, which seems to be effective in the treatment of CIN lesions with minimal side effects, with faster resolution and longer tumor-free period compared to other studies using interferon alfa-2b alone [27].

In a large study conducted at the Bascon Palmer Eye Institute from 2001 to 2010, the recurrence rate in patients treated with IFNa2b at 1 year was $10 \%$ and $21 \%$ at 5 years. In those patients with positive margins of lesions, the use of postoperative topical therapy reduced the recurrence rate to a level similar to patients with negative margins [28]. Other comparative studies report recurrence rates between surgery and topical therapy at 1 year of $5 \%$ in surgery groups versus $3 \%$ in the IFNa2b groups. This leads us to conclude that both topical IFNa2b and surgical excision appear to be effective for the primary OSSN [29,30].

The efficiency of interferon in pigmented lesions has been documented in some studies, but its use has not been as well studied as with MMC, but even in some patients with recurrences to other treatments it has shown to be effective [31]. In both precursor lesions as PAM with atypia or conjunctival melanoma, Garip, et al. demonstrated a mean decrease in tumor size of $66 \%$ after a first treatment cycle, 55\% after a second and up to $74 \%$ after a third cycle showing promising results with minimal side effects [32].

\section{Use of interferon in other disease}

IFN-a, IFN-b and IFN-g type interferons exist in recombinant form and are used in a clinical setting for the treatment of various immunosuppressive diseases such as Kaposi's sarcoma in HIV / AIDS, hepatitis type $\mathrm{B}$ and $\mathrm{C}$, condylomata acuminata, multiple sclerosis, gliomas and herpes virus or HPV infections (IFN-b) [3335]. In addition, IFN-a2b has been tested in patients with Behcet uveitis relapsed to corticosterides and patients with multiple sclerosis (MS), as well as systemically recombinant human interferon alfa-2a (rhIFNa-2a) at doses of 6 million units subcutaneously per day has had positive results, improving vision and in some cases a complete remission of ocular vasculitis 
in ocular Behcet and multiple sclerosis [36-39]. Some findings suggest that IFN plays a key role in promoting conjunctival squamous metaplasia and apoptosis in dry eye and provide information on the immune response of keratoconjunctivitis sicca $[40,41]$.

\section{Mitomycin C}

The uses of MMC on ocular surface have been widely studied. Topical MMC application is an effective treatment for squamous intraepithelial lesions and even conjunctival squamous cell carcinoma with excellent long-term results [42-45]. MMC is an antineoplastic antibiotic (alkylating agent) isolated from Streptomyces caespitosus that acts inhibiting DNA synthesis [46].

Combination therapies with mitomycin seem promising. Its use with topical cyclosporin A (0.05\%) combined with mitomycin $C(0.01 \%)$ as adjunctive treatment after surgical excision in cornea and conjunctival intraepithelial neoplasia and squamous cell carcinoma prevents tumor recurrence especially in extensive lesions, when surgical excision cannot guarantee a tumor-free margin or even in failed IFNa2b treatment [47-49].

In pigmented lesions, variable responses have been reported. Side effects of local chemotherapy generally resolve after treatment interruption, being a good alternative to surgical excision and cryotherapy in treatment of nevi with atypia, PAM with atypia and even melanoma [50-52]. Treatment with topical MMC not only reduces the size and degree of clinical pigmentation lesions, in conjunctiva and lesions involving corneal epithelium, but also eradicates residual atypical conjunctival melanocytes $[53,54]$.

Its use as an adjuvant agent after completed surgical resection $[55,56]$ has been corroborated in many studies. Birkholz, et al. complementary used of MMC with a significantly reduced prevalence of recurrence of $5.9 \%$ vs. $66.7 \%$ when it was not used. In invasive melanomas and adjuvant brachytherapy achieves high rates of local tumor control with little ocular morbidity, except in nodular tumors where they appear to be resistant to topical chemotherapy with MMC. Without caruncular involvement, disease-specific mortality is rare $[57,58]$ and when surgical margins are positive in extensive lesions, the use of MMC is associated with a lower prevalence of tumor recurrence $[59,60]$. Long-term studies have evaluated the recurrence and effectiveness of MMC in neoplastic pigmented lesions, such as the study by Kurly and Finger, which followed a 12-year follow-up in patients with PAM with atypia and conjunctival melanoma. Both entities responded to topical chemotherapy with 0.04\% MMC; Subepithelial nests were resistant to treatment, and they concluded that as primary or adjunctive therapy, topical MMC produced an overall recurrence rate of 50\% [61].

\section{5-Fluorouracilo}

5-Fluorouracil (5-FU) is an effective and well tolerated agent as primary treatment for OSSN, with up to an $82 \%$ favorable response rate [62]. Despite being a treatment sparsely used nowadays due to the rise of new therapies such as IFNa2b [67], topical 5-FU, as single or combined therapy, can be considered a safe and effective long-term treatment for OSSN as corneal toxicity is minimal [63].

Several comparative studies have been conducted of measure the efficacy of topical treatment with 5-FU and IFNa2b $(1 \mathrm{MIU} / \mathrm{ml})$ as primary treatment modalities for OSSN. Both modalities have yielded similar results with a high rate of lesion resolution and low recurrence. Usually, doses used topically are 4 times a day for 1 week followed by a 3-week drug break $[64,65]$.

Subconjunctival/perilesional 5-FU injections are also an effective and safe treatment for OSSN. In a study carried out by Sun \& Hua in China they used 10 to 25 injection doses, with an average duration of treatment between 6 to 20 weeks, resulting in the disappearance of both intratumoral and conjunctival feeding vessels in OSSN demonstrated by OCT-AS [66].

\section{Side Effects of Topical Therapies}

\section{Interferon}

The adverse effects of topical use of interferon have been widely studied and described. Even the systemic use has repercussion in different presentations, from effects at the anterior segment to secondary retinopathies including retinal ischemia, choroidal neovascularization and ischemic optic neuropathy [68-72]. Retinal changes are usually reversible with discontinuation of therapy. Local adverse effects include conjunctival hyperemia, follicular hypertrophy, giant papillary conjunctivitis, irritation, epithelial corneal defects, and flu-like symptoms. All these effects usually resolve on average one month after discontinuation the medication [73].

Galor, et al, concluded that there were no significant differences between patients who used doses of 1 million $\mathrm{IU} / \mathrm{ml}$ versus 3 million $\mathrm{IU} / \mathrm{ml}$ for the treatment of conjunctival intraepithelial neoplasms (CIN) topically with results and similar side effects. The average duration of treatment is variable and in most of the studies it has been used until lesions are resolved, all side effects generally disappear when the treatment is suspended. For melanocytic lesions, topical doses of 1 drop 5 times a day for 6 weeks are suggested with few or no side effects $[75,16]$.

\section{Mitomycin C}

In the largest study of topical MMC complications in ocular surface neoplasia by Khong \& Muecke (2006), allergic reaction and point stenosis were the 
most common complications with no medium-term complications [76].

Histologically, nuclear enlargement, cellular hyperchromasia in the superficial layers of the epithelium were the main secondary effects observed. Cytoplasmic eosinophilia, unicellular necrosis, and occasionally chronic subepithelial inflammation were also observed [77,78]. Ditta, et al. evaluated the long-term complications (6 months) of MMC therapy in patients with conjunctival melanoma. The most common complications included injection, tearing, irritation, pain, and limbal stem cell deficiency [46]. Other complications reported have been keratopathy, cataract [79] or even metastasis [80], according to the same authors could be associated with treatment delay.

\section{5-Fluorouracilo}

Some of the adverse effects reported are conjunctival inflammation, epithelial defects, skin and epiphora erythema. The use of subconjunctival injections of
5-FU after glaucoma surgery can lead to squamous metaplastic changes and nuclear atypia and apoptotic cell death in the conjunctival epithelium in a short period. Adverse effects are generally transient and mild $[62,81]$.

\section{Conclusion}

Topical or perilesional chemotherapy on the ocular surface as a single therapeutic agent has proven to be an effective treatment avoiding the risks of repeated surgical interventions and their effects such as scar conjunctival changes. The three drugs revised in this study seems to be effective and safe, but larger controlled studies with longer follow-up periods are recommended to confirm long-term efficacy and safety of these treatments. Its use for residual or recurrent lesions should be carefully considered and closely monitored to avoid metastasis, especially in melanocytic lesions. The main results and recommended doses of the larger studies included in this review are summarize in Table 1.

Table 1: Summary of effectiveness of the different topical therapies per study.

\begin{tabular}{|c|c|c|c|c|}
\hline \multirow[b]{2}{*}{$\begin{array}{l}\text { Study (year } \\
\text { of publication } \\
\text { and number of } \\
\text { patients in each } \\
\text { study) }\end{array}$} & \multicolumn{3}{|c|}{ Main Results } & \multirow[b]{2}{*}{ Used Doses } \\
\hline & IFNa2b & MMC & 5-FU & \\
\hline $\begin{array}{l}\text { Venkateswaran, } \\
\text { et al. [64] }\end{array}$ & $\begin{array}{l}81.3 \% \text { resolution (n: } \\
48) \\
(\mathrm{OSSN})\end{array}$ & & $\begin{array}{l}\text { 96.3\% effectiveness ( } \mathrm{n} \text { : } \\
\text { 54) (OSSN) }\end{array}$ & $\begin{array}{l}5 F U 1 \%, 4 x / \text { day for } \\
\text { one week/monthly) ultil } \\
\text { resolution. } \\
\text { IFN } 1 \mathrm{MIU} / \mathrm{mL} .4 x / \text { day } \\
\text { continuously. }\end{array}$ \\
\hline $\begin{array}{l}\text { Pe'er, et al. } \\
\text { [50] }\end{array}$ & & $>80 \%$ (n: 12) (PAM) & & $\begin{array}{l}\text { Two to five courses of } \\
0.04 \%(0.4 \mathrm{mg} / \mathrm{ml}) \mathrm{MMC}\end{array}$ \\
\hline Galor, et al. [28] & $\begin{array}{l}81 \% \text { of eyes in the } 1 \\
\text { million IU/ml group vs. } \\
92 \% \text { in the } 3 \text { million } \\
\text { IU/ml group. (CIN) }\end{array}$ & & & $\begin{array}{l}10 \text { patients were treated } \\
\text { with } 1 \text { million IU/ ml of } \\
\text { topical IFN-a2b; } 9 \text { patients } \\
\text { were treated with } 3 \text { million } \\
\text { IU/ml of topical IFN-a2b. } \\
\text { Both groups used } 4 x / \text { daily }\end{array}$ \\
\hline $\begin{array}{l}\text { Birkholz, et al. } \\
\text { [59] }\end{array}$ & & $\begin{array}{l}\text { Significantly reduced } \\
\text { prevalence of recurrence } \\
(5.9 \% \text { vs. } 66.7 \%) \text {. In } \\
\text { positive surgical margins, } \\
\text { MMC reduced the tumor } \\
\text { recurrence }(12.5 \% \text { vs. } \\
55.6 \%) \text {. With negative } \\
\text { margins, MMC reduced } \\
\text { recurrence (0\% vs. } 83.3 \%) \\
(\text { OSSN) }\end{array}$ & & $\begin{array}{l}\text { Weck cel sponge soaked } \\
0.02 \% \text { or } 0.04 \% \text { of MMC } \\
\text { to the subconjunctival } \\
\text { surface at the edge of } \\
\text { the surgical excision for } \\
1-3 \text { min. Postop, } 1 \text { drop } \\
\text { of topical MMC } 0.02 \% 3 \\
\text { times daily for } 2 \text { weeks. In } \\
\text { most cases, } 3 \text { cycles of } 2 \\
\text { weeks on and } 2 \text { weeks off } \\
\text { were used. }\end{array}$ \\
\hline Boehm [74] & $\begin{array}{l}85 \% \text { successful rate. } \\
\text { (OSSN) }\end{array}$ & & & $\begin{array}{l}1 \text { million } \mathrm{IU} / \mathrm{ml} 4 \text { times daily } \\
\text { until lesion resolution }\end{array}$ \\
\hline
\end{tabular}




\begin{tabular}{|c|c|c|c|}
\hline Zaki, et al. [47] & & $\begin{array}{l}\text { All eyes showed total } \\
\text { cure with no recurrence } \\
\text { during the 2-year follow-up } \\
\text { period. }\end{array}$ & $\begin{array}{l}\text { Topical cyclosporine } \\
\text { A }(0.05 \%) \text { and topical } \\
\text { mitomycin C }(0.01 \%) 4 \\
\text { times daily for } 12 \text { weeks } \\
\text { after surgery. }\end{array}$ \\
\hline Shah, et al. [73] & $\begin{array}{l}\text { Complete resolution } \\
\text { in } 19 \\
\text { tumors }(83 \%) \text {. Partial } \\
\text { resolution }(17 \%) \text {, } \\
\text { tumor surface area } \\
\text { was reduced } 44 \% \\
\text { (median). } \\
\text { (OSSN) }\end{array}$ & & $\begin{array}{l}\text { Topical interferon alfa- } 2 b \text {, } \\
1 \text { million } \\
\text { IU } / \mathrm{mL}, 4 \text { times daily }\end{array}$ \\
\hline $\begin{array}{l}\text { B. Damato and SE } \\
\text { Couplan [57] }\end{array}$ & & $\begin{array}{l}\text { Excision of invasive } \\
\text { melanoma } \\
\text { with adjunctive } \\
\text { brachytherapy and topical } \\
\text { chemotherapy, recurrence } \\
\text { occurred in six patients. (if } \\
\text { treatment did not include } \\
\text { radiotherapy) } \\
\text { (Conjunctival melanoma) }\end{array}$ & $\begin{array}{l}\text { Topical MMC } 0.02 \% \text {, four } \\
\text { times daily for a total of } 4 \\
\text { weeks, initially in two } 14- \\
\text { day } \\
\text { cycles, separated by } \\
\text { a } 2 \text {-week interval, and } \\
\text { latterly in } \\
\text { four } 7 \text {-day cycles over } 8 \\
\text { weeks. }\end{array}$ \\
\hline $\begin{array}{l}\text { T Finger, et al. } \\
(1997) \mathrm{n}: 10\end{array}$ & & $\begin{array}{l}\text { Decreased conjunctival } \\
\text { pigmentation in the four } \\
\text { patients where topical } \\
\text { chemotherapy was used } \\
\text { as a primary. treatment. } \\
\text { Nodular tumors were } \\
\text { resistant to topical MMC } \\
\text { chemotherapy. (PAM with } \\
\text { atypia) }\end{array}$ & $\begin{array}{l}0.04 \% \text { MMC ophthalmic } \\
\text { solution } \\
\text { each week for } 28 \text { days. } \\
\text { When was used as an } \\
\text { adjuvant, drops were given } \\
\text { for } 7 \text { days starting within } 2 \\
\text { weeks of primary excision } \\
\text { and cryotherapy }\end{array}$ \\
\hline $\begin{array}{l}\text { T. Finger, et al. } \\
\text { [31] }\end{array}$ & $\begin{array}{l}\text { Patients with T2 and } \\
\text { T3 of } \\
\text { AJCC. } 2 \text { patients had } \\
\text { regression of recurrent } \\
\text { disease. } \\
\text { (Conjunctival } \\
\text { melanoma) }\end{array}$ & & $\begin{array}{l}\text { One drop of interferon alfa- } \\
2 \mathrm{~b}(1 \\
\text { million units/ml) was } \\
\text { placed into the superior } \\
\text { fornix four times daily for } \\
\text { three months. }\end{array}$ \\
\hline $\begin{array}{l}\text { Frucht-Pery, et al. } \\
\text { [78] }\end{array}$ & & $\begin{array}{l}10 \text { patients had disease- } \\
\text { free after one course of } \\
\text { treatment. } 1 \text { case, residual } \\
\text { CCIN remained very small } \\
\text { without regrowth. In the } \\
\text { one patient with invasive } \\
\text { SCC and in } 5 \text { patients with } \\
\text { CCIN, regrowth occurred } \\
\text { after } 6 \text { months. }\end{array}$ & $\begin{array}{l}\text { MMC } 0.02 \% \text { to } 0.04 \% \text { four } \\
\text { times } \\
\text { daily from } 7 \text { to } 28 \text { days. }\end{array}$ \\
\hline Garip, et al. [32] & $\begin{array}{l}\text { Decrease in tumor } \\
\text { size after the first cycle } \\
66 \% \text {, after the second } \\
\text { cycle } 55 \% \text {, and after } \\
\text { the third cycle } 74 \% \text {. } \\
\text { (Melanoma and PAM } \\
\text { with atypia) }\end{array}$ & & $\begin{array}{l}\text { IFNa-2b, } 1 \text { million units/ } \\
\text { ml, } 5 \text { times daily (range } 1-6 \\
\text { cycle). }\end{array}$ \\
\hline Halas, et al. [52] & & $\begin{array}{l}\text { Topical therapy after } \\
\text { primary excision. No } \\
\text { presence of relapse of } \\
\text { pigmentation in excision } \\
\text { area with or without using } \\
\text { MMC during the surgery in } \\
\text { patients with PAM. }\end{array}$ & $\begin{array}{l}\text { MMC }(0.04 \%=0.4 \mathrm{mg} / \mathrm{l}) \\
\text { as a topic treatment after } \\
\text { excision two times for } \\
5 \mathrm{~min} \text { in the operating } \\
\text { room. The patients did not } \\
\text { receive MMC fluid for use } \\
\text { at home. }\end{array}$ \\
\hline
\end{tabular}




\begin{tabular}{|c|c|c|c|c|}
\hline $\begin{array}{l}\text { Herold \& } \\
\text { Hintschich [75] }\end{array}$ & & $\begin{array}{l}9 \text { patients showed } \\
\text { regression and lost } \\
\text { pigmentation. } 3 \text { patients } \\
\text { required a second cycle } \\
\text { (PAM with atypia and/or } \\
\text { conjunctival melanoma) }\end{array}$ & & $\begin{array}{l}5 \times 1 \text { drop/day topically for } \\
6 \text { weeks. }\end{array}$ \\
\hline $\begin{array}{l}\text { Holcombe, et al. } \\
\text { [18] }\end{array}$ & $\begin{array}{l}8 \text { of } 10 \text { patients } \\
\text { achieved clinical } \\
\text { resolution from topical } \\
\text { IFN-_2b treatment. } \\
1 \text { patient developed } \\
\text { invasive SCC }\end{array}$ & & & $\begin{array}{l}\text { Topical IFNa2b ( } 1 \text { million } \\
\text { IU/ml) four times a day } \\
\text { until clinical resolution or } \\
\text { until the lesion appeared } \\
\text { nonresponsive. }\end{array}$ \\
\hline Joag, et al. [62] & & & $\begin{array}{l}\text { Complete resolution } \\
\text { of OSSN in } 82 \% \text { of } \\
\text { patients; } 18 \% \text { were } \\
\text { considered treatment } \\
\text { nonresponders. }\end{array}$ & $\begin{array}{l}\text { 5-FU } 1 \% \text { topically } 4 \text { times } \\
\text { daily for } 1 \text { week followed } \\
\text { by a drug holiday of } 3 \\
\text { weeks. (Mean: } 4 \text { cycles) }\end{array}$ \\
\hline Karp, et al. [19] & $\begin{array}{l}\text { All patients had } \\
\text { complete resolution } \\
\text { of the CIN lesion. } \\
\text { Mean time to clinical } \\
\text { resolution was } 11.6 \\
\text { weeks. }\end{array}$ & & & $\begin{array}{l}\text { Topical IFNa2b million IU/ } \\
\text { ml four times a day, until } \\
\text { clinical resolution. }\end{array}$ \\
\hline Kim, et al. [24] & $\begin{array}{l}\text { In } 72 \% \text { of giant } \\
\text { OSSNs IFNa2b } \\
\text { achieved } \\
\text { complete control } \\
\text { (immunotherapy); } \\
\text { there was a } \\
\text { reduction in size } \\
\text { (immunoreduction) in } \\
28 \% \text { of giant OSSNs. }\end{array}$ & & & $\begin{array}{l}\text { Patients with giant OSSN } \\
\text { was managed with topical } \\
\text { IFNa2b (1 million IU/ml) } 4 \\
\text { times daily or with injection } \\
\text { IFN_2b (a portion of } 10 \\
\text { million IU/ml vial) }\end{array}$ \\
\hline $\begin{array}{l}\text { Krilis, et al (2012) } \\
\text { n: } 89\end{array}$ & $\begin{array}{l}\text { Complete resolution } \\
\text { of the CIN lesions was } \\
\text { in } 87 \text { of the } 89 \text { eyes } \\
\text { treated. }(97.75 \%) .\end{array}$ & & & $\begin{array}{l}1 \text { million IU/ml drops } 4 \\
\text { times daily and retinoic } \\
\text { acid } 0.01 \% \text { once every } \\
\text { second day. }\end{array}$ \\
\hline $\begin{array}{l}\text { Kusumesh, et al. } \\
\text { [12] }\end{array}$ & $\begin{array}{l}\text { Complete remission } \\
\text { of the tumor was } \\
\text { observed in } 22 \\
\text { patients }(91.6 \%) .8 .3 \% \\
\text { did not respond to the } \\
\text { treatment. }\end{array}$ & & & $\begin{array}{l}\text { Topical IFNa2b ( } 1 \text { million } \\
\text { IU/mL) } 4 \text { times daily until } \\
\text { resolution. }\end{array}$ \\
\hline $\begin{array}{l}\text { Parrozzani, et al. } \\
\text { [63] }\end{array}$ & & & $\begin{array}{l}\text { Complete regression } \\
\text { was achieved in } \\
\text { all patients. Only } 3 \\
\text { patients }(7.3 \%) \text { treated } \\
\text { with } 5 \text {-FU alone } \\
\text { recurred. Recurrences } \\
\text { were successfully } \\
\text { treated with additional } \\
5 \text {-FU courses. }\end{array}$ & $\begin{array}{l}\text { Topical 5-FU four times/ } \\
\text { day for } 4 \text { weeks (one } \\
\text { course until clinical } \\
\text { and cytological tumour } \\
\text { regression.). }\end{array}$ \\
\hline Shields, et al. [24] & & $\begin{array}{l}\text { Complete tumor } \\
\text { regression in } 100 \% \text { of } \\
\text { the cases was achive in } \\
\text { conjunctival or corneal } \\
\text { SCC, even in extensive } \\
\text { recurrent tumor }\end{array}$ & & $\begin{array}{l}\text { Topical MMC } 0.04 \% \text { one } \\
\text { drop four times daily } / 1 \\
\text { week followed by } 1 \text { week } \\
\text { without medication. }\end{array}$ \\
\hline
\end{tabular}




\begin{tabular}{|c|c|c|c|c|}
\hline Shields, et al. [22] & $\begin{array}{l}\text { IFNa2b } \\
\text { immunotherapy } \\
\text { complete response } \\
\text { in } 75 \% \text { Tis, in } 100 \% \\
\text { of T1, and in } 70 \% \\
\text { T3. In combination } \\
\text { with surgical excision } \\
\text { achieved tumor } \\
\text { control in } 100 \% \text { Tis, } \\
\text { in } 100 \% \mathrm{~T} 1 \text {, in } 100 \% \\
\text { T2, in } 100 \% \text { T3, and } \\
\text { in } 100 \% \text {. Topical and/ } \\
\text { or injection) was used } \\
\text { as alone or combined } \\
\text { with additional surgery, } \\
\text { complete tumor control } \\
\text { was achieved } 95 \% \text {. }\end{array}$ & & & $\begin{array}{l}\text { The topical IFNa2b eye } \\
\text { drops were prepared at } \\
\text { a dose of } 1 \mathrm{MIU} / \mathrm{m} \text {. The } \\
\text { IFNa2b injection was } 1-\mathrm{mL} \\
\text { syringe with undiluted } \\
\text { Intron-A }(10 \mathrm{MIU} / \mathrm{mL}) \text {. }\end{array}$ \\
\hline Sturges, et al. [29] & $\begin{array}{l}\text { Comparative study: } 15 \\
\text { patients elected topical } \\
\text { IFNa2b and } 14 \text { chose } \\
\text { surgical excision. } \\
\text { No patient in either } \\
\text { group developed a } \\
\text { recurrence during the } \\
\text { study period (primary } \\
\text { OSSN) }\end{array}$ & & & $\begin{array}{l}\text { Topical INFa2b ( } 1 \text { million } \\
\text { U/ml) } 4 \text { time per day until } \\
\text { clinical resolution. }\end{array}$ \\
\hline Vann, et al. [23] & $\begin{array}{l}\text { All six patients had } \\
\text { complete clinical } \\
\text { resolution of the } \\
\text { CIN lesion within } 6 \\
\text { weeks of initiation of } \\
\text { treatment. }\end{array}$ & & & $\begin{array}{l}\text { Single subconjunctival/ } \\
\text { perilesional injection of } \\
\text { recombinant IFNa2b } \\
3 \text { million (IU) in } 0.5 \mathrm{ml} \text { and } \\
\text { then started topical INFa2b } \\
\text { drops ( } 1 \text { million } \mathrm{U} / \mathrm{ml} \text { ) four } \\
\text { times a day }\end{array}$ \\
\hline $\begin{array}{l}\text { Prabhasawat, et } \\
\text { al. }\end{array}$ & & $\begin{array}{l}\text { Before MMC treatment, } \\
6 \text { eyes }(85.7 \%) \text { had } \\
\text { recurrences after surgical } \\
\text { excision. The tumor-free } \\
\text { period ranged from } 2 \text { to } 19 \\
\text { months. Two patients had } \\
\text { multiple recurrences. }\end{array}$ & & $\begin{array}{l}\text { Topical } 0.002 \% \text { MMC } 4 \\
\text { times } \\
\text { daily. ( } 2-14 \text { cycles })\end{array}$ \\
\hline Ballalai, et al. [45] & & $\begin{array}{l}\text { Complete resolution of the } \\
\text { lesion was achieved in } \\
\text { all patients after } 1 \text { month } \\
\text { of treatment. Recurrence } \\
\text { occurred in } 1 \text { patient } \\
(4.3 \%) \text { after } 24 \text { months of } \\
\text { treatment }\end{array}$ & & $\begin{array}{l}\text { Topical MMC } 0.02 \% \text {, } \\
\text { four times per day, for } 28 \\
\text { consecutive days. }\end{array}$ \\
\hline $\begin{array}{l}\text { Chen, Louis, } \\
\text { Dodd, et al. [60] }\end{array}$ & & $\begin{array}{l}\text { All the lesions were } \\
\text { completely excised } \\
\text { superficially from the } \\
\text { cornea and limbus with } \\
\text { a } 2 \text { mm margin on the } \\
\text { conjunctival aspect. There } \\
\text { was no evidence of clinical } \\
\text { recurrence in any cases }\end{array}$ & & $\begin{array}{l}\text { Topical MMC } 0.04 \% \text { four } \\
\text { times a day per } 1 \text {-week, } \\
\text { at least two courses or } \\
\text { after completing epithelial } \\
\text { healing. }\end{array}$ \\
\hline Sun and Hua [66] & & & $\begin{array}{l}3 \text { years after initiation } \\
\text { of treatment complete } \\
\text { tumor regression to } \\
\text { final visit according to } \\
\text { AS-OCT was } 32.5 \pm 4.2 \\
\text { months (OSSN) }\end{array}$ & $\begin{array}{l}\text { Subconjunctival/ } \\
\text { perilesional } 5 \mathrm{FU} \text { injections } \\
\text { (mean number of doses } \\
17.0 \pm 8.6 \text { ) }\end{array}$ \\
\hline Gichuhi, et al. [67] & & & $\begin{array}{l}\text { Comparative study: } \\
\text { Aftersurgical excision } \\
\text { of OSSN, recurrences } \\
\text { occurred in } 11 \% \text { of } 5 \mathrm{FU} \\
\text { group, and } 36 \% \text { of } 47 \text { in } \\
\text { the placebo group. }\end{array}$ & $\begin{array}{l}\text { Topical } 5 F U 1 \% \text { or placebo } \\
\text { four times a day for } 4 \\
\text { weeks. }\end{array}$ \\
\hline
\end{tabular}




\section{References}

1. Stone DU, Butt AL, Chodosh J (2005) Ocular surface squamous neoplasia: A standard of care survey. Cornea 24: $297-300$.

2. Yousef YA, Finger PT (2012) Squamous carcinoma and dysplasia of the conjunctiva and cornea: An analysis of 101 cases. Ophthalmology 119: 233-240.

3. Abou Shousha M, Karp CL, Canto AP, Hodson K, Oellers P, et al. (2013) Diagnosis of ocular surface lesions using ultra-high-resolution optical coherence tomography. Ophthalmology 120: 883-891.

4. Abou Shousha M, Karp CL, Perez VL, Hoffmann R, Ventura $R$, et al. (2011) Diagnosis and management of conjunctival and corneal intraepithelial neoplasia using ultra highresolution optical coherence tomography. Ophthalmology 118: 1531-1537.

5. Singh S, Mittal R, Ghosh A, Tripathy D, Rath S (2018) High-Resolution Anterior Segment Optical Coherence Tomography in Intraepithelial Versus Invasive Ocular Surface Squamous Neoplasia. Cornea 37: 1292-1298.

6. Sonawane S, Khanolkar V, Namavari A, Chaudhary S, Gandhi S, et al. (2012) Ocular surface extracellular DNA and nuclease activity imbalance: A new paradigm for inflammation in dry eye disease. Invest Ophthalmol Vis Sci 53: 8253-8263.

7. Tibrewal S, Sarkar J, Jassim SH, Gandhi S, Sonawane S, et al. (2013) Tear fluid extracellular DNA: Diagnostic and therapeutic implications in dry eye disease. Invest Ophthalmol Vis Sci 54: 8051-8061.

8. Chen Y, Chauhan SK, Saban DR, Sadrai Z, Okanobo A, et al. (2011) Interferon- $y$-secreting NK cells promote induction of dry eye disease. J Leukoc Biol 89: 965-972.

9. Plskova J, Greiner K, Forrester JV (2007) Interferon-a as an effective treatment for noninfectious posterior uveitis and panuveitis. Am J Ophthal 144: 55-61.

10. Lane AM, Egan KM, Harmon D, Holbrook A, Munzenrider JE, et al. (2009) Adjuvant interferon therapy for patients with uveal melanoma at high risk of metastasis. Ophthalmology 116: 2206-2212.

11. Bahrami B, Greenwell T, Muecke JS (2014) Long-term outcomes after adjunctive topical 5-flurouracil or mitomycin $C$ for the treatment of surgically excised, localized ocular surface squamous neoplasia. Clin Exp Ophthal 42: $317-$ 322.

12. Kusumesh R, Ambastha A, Sinha B, Kumar R (2015) Topical interferon $a-2 b$ as a single therapy for primary ocular surface squamous neoplasia. Asia Pac J Ophthalmol (Phila) 4: 279-282.

13. Schechter BA, Schrier A, Nagler RS, Smith EF, Velasquez GE (2002) Regression of presumed primary conjunctival and corneal intraepithelial neoplasia with topical interferon alpha-2b. Cornea 21: 6-11.

14. Li AS, Shih CY, Rosen L, Steiner A, Milman T, et al. (2015) Recurrence of ocular surface squamous neoplasia treated with excisional biopsy and cryotherapy. Am J Ophthalmol 160: 213-219.

15. Peksayar G, Altan-Yaycioglu R, Onal S (2003) Excision and cryosurgery in the treatment of conjunctival malignant epithelial tumours. Eye 17: 228-232.

16. Kaliki S, Singh S, Iram S, Tripuraneni D (2016) Recombinant interferon alpha $2 \mathrm{~b}$ for ocular surface squamous neoplasia:
An efficient and cost-effective treatment modality in Asian Indian patients. Indian J Ophthalmol 64: 702.

17. Moon CS, Nanji AA, Galor A, McCollister KE, Karp CL (2016) Surgical versus medical treatment of ocular surface squamous neoplasia: A cost comparison. Ophthalmology 123: 497-504.

18. Holcombe DJ, Lee GA (2006) Topical interferon alfa-2b for the treatment of recalcitrant ocular surface squamous neoplasia. Am J Ophthalmol 142: 568-571.

19. Karp CL, Moore JK, Rosa Jr RH (2001) Treatment of conjunctival and corneal intraepithelial neoplasia with topical interferon a-2b. Ophthalmology 108: 1093-1098.

20. Schechter BA, Rand WJ, Velazquez GE, Williams WD, Starasoler $L$ (2002) Treatment of conjunctival papillomata with topical interferon Alfa-2b. Am J Ophthalmol 134: 268270.

21. Karp CL, Galor A, Chhabra S, Barnes SD, Alfonso EC (2010) Subconjunctival/perilesional recombinant interferon $\alpha 2 b$ for ocular surface squamous neoplasia: A 10-year review. Ophthalmology 117: 2241-2246.

22. Shields CL, Kaliki S, Kim HJ, Al-Dahmash S, Shah SU, et al. (2013) Interferon for ocular surface squamous neoplasia in 81 cases: Outcomes based on the American Joint Committee on Cancer classification. Cornea 32: 248-256.

23. Vann RR, Karp CL (1999) Perilesional and topical interferon alfa-2b for conjunctival and corneal neoplasia. Ophthalmology 106: 91-97.

24. Kim HJ, Shields CL, Shah SU Kaliki S, Lally SE (2012) Giant ocular surface squamous neoplasia managed with interferon alpha-2b as immunotherapy or mmunoreduction. Ophthalmology 119: 938-944.

25. Mackensen F, Jakob E, Springer C, Dobner BC, Wiehler U, et al. (2013) Interferon versus methotrexate in intermediate uveitis with macular edema: results of a randomized controlled clinical trial. Am J Ophthalmol 156: 478-486.

26. Miller JW, Stinson WG, Folkman J (1993) Regression of experimental iris neovascularization with systemic alphainterferon. Ophthalmology 100: 9-14.

27. Krilis $M$, Tsang $H$, Coroneo $M$ (2012) Treatment of conjunctival and corneal epithelial neoplasia with retinoic acid and topical interferon alfa-2b: Long-term followup. Ophthalmology 119: 1969-1973.

28. Galor A, Karp CL, Oellers P, Kao AA, Abdelaziz A, et al. (2012) Predictors of ocular surface squamous neoplasia recurrence after excisional surgery. Ophthalmology 119: 1974-1981.

29. Sturges A, Butt AL, Lai JE, Chodosh J (2008) Topical interferon or surgical excision for the management of primary ocular surface squamous neoplasia. Ophthalmology 115: 1297-1302.

30. Nanji AA, Moon CS, Galor A, Sein J, Oellers P, et al. (2014) Surgical versus medical treatment of ocular surface squamous neoplasia: A comparison of recurrences and complications. Ophthalmology 121: 994-1000.

31. Finger PT, Sedeek RW, Chin K J (2008) Topical interferon alfa in the treatment of conjunctival melanoma and primary acquired melanosis complex. Am J Ophthalmol 145: 124129.

32. Garip A, Schaumberger MM, Wolf A, Herold TR, Miller CV, et al. (2016) Evaluation of a short-term topical interferon $a-2 b$ treatment for histologically proven melanoma and primary acquired melanosis with atypia. Orbit 35: 29-34. 
33. Mlakar J, Kocjan BJ, Hošnjak L, Pižem J, Beltram M, et al. (2015) Morphological characteristics of conjunctival squamous papillomas in relation to human papillomavirus infection. Br J Ophthalmol 99: 431-436.

34. Tulvatana W, Bhattarakosol P, Sansopha L, Sipiyarak W, Kowitdamrong E, et al. (2003) Risk factors for conjunctival squamous cell neoplasia: A matched case-control study. $\mathrm{Br}$ J Ophthalmol 87: 396-398.

35. Guthoff R, Marx A, Stroebel P (2009) No evidence for a pathogenic role of human papillomavirus infection in ocular surface squamous neoplasia in Germany. Curr Eye Res 34: 666-671.

36. Sobacı G, Erdem Ü, Durukan AH, Erdurman C, Bayer A, et al. (2010) Safety and effectiveness of interferon alpha-2a in treatment of patients with Behçet's uveitis refractory to conventional treatments. Ophthalmology 117: 1430-1435.

37. Bodaghi B, Gendron G, Wechsler B, Terrada C, Cassoux $\mathrm{N}$, et al. (2007) Efficacy of interferon alpha in the treatment of refractory and sight threatening uveitis: a retrospective monocentric study of 45 patients. $\mathrm{Br} \mathrm{J}$ Ophthalmol 91: 335339.

38. Kötter I, Zierhut M, Eckstein AK, Vonthein R, Ness T, et al. (2003) Human recombinant interferon alfa-2a for the treatment of Behcet's disease with sight threatening posterior or panuveitis. Br J Ophthalmol 87: 423-431.

39. Becker MD, Heiligenhaus A, Hudde T, Storch-Hagenlocher B, Wildemann B, et al. (2005) Interferon as a treatment for uveitis associated with multiple sclerosis. $\mathrm{Br} J$ Ophthalmol 89: 1254-1257.

40. De Paiva CS, Villarreal AL, Corrales RM, Rahman HT, Chang VY, et al. (2007) Dry eye-induced conjunctival epithelial squamous metaplasia is modulated by interferon- $\gamma$. Invest Ophthalmol Vis Sci 48: 2553-2560.

41. Zhang X, Chen W, De Paiva CS, Corrales RM, Volpe $E A$, et al. (2011) Interferon- $y$ exacerbates dry eyeinduced apoptosis in conjunctiva through dual apoptotic pathways. Invest Ophthalmol Vis Sci 52: 6279-6285.

42. Frucht-Pery J, Rozenman Y, Pe'er J (2002) Topical mitomycin-C for partially excised conjunctival squamous cell carcinoma. Ophthalmology 109: 548-552.

43. Shields CL, Naseripour M, Shields JA (2002) Topical mitomycin $C$ for extensive, recurrent conjunctival-corneal squamous cell carcinoma. Am J Ophthalmol 133: 601-606.

44. Wilson MW, Hungerford JL, George SM, Madreperla SA (1997) Topical mitomycin C for the treatment of conjunctival and corneal epithelial dysplasia and neoplasia. Am J Ophthalmol 124: 303-311.

45. Ballalai PL, Erwenne CM, Martins MC, Lowen MS, Barros JN (2009) Long-Term Results of Topical Mitomycin C $0.02 \%$ for Primary and Recurrent Conjunctival-Corneal Intraepithelial Neoplasia, Ophthalmic Plast Reconstr Surg 25: 296-299.

46. Hirst LW (2007) Randomized controlled trial of topical mitomycin C for ocular surface squamous neoplasia: Early resolution. Ophthalmology 114: 976-982.

47. Zaki AA, Farid SF (2009) Management of Intraepithelial and Invasive Neoplasia of the Cornea and Conjunctiva: A Long-Term Follow Up. Cornea 28: 986-988.

48. Huerva V, Mateo AJ, Mangues I, Jurjo C (2006) Short-Term Mitomycin C Followed By Long-Term Interferon $\alpha 2 \beta$ for Conjunctiva-Cornea Intraepithelial Neoplasia, Cornea 25 : 1220-1223.
49. Arman A, Demirseren DD, Takmaz T (2015) Treatment of ocular rosacea: Comparative study of topical cyclosporine and oral doxycycline. Int J Ophthalmol 8: 544-549.

50. Pe'er J, Frucht-Pery J (2005) The treatment of primary acquired melanosis (PAM) with atypia by topical Mitomycin C. Am J Ophthalmol 139: 229-234.

51. Anandajeya WV, Corrêa ZM, Augsburger JJ (2009) Primary acquired melanosis with atypia treated with mitomycin C. Int Ophthalmol 285-288.

52. Halas JM, Svetlosakova Z, Babal P (2013) Therapy of melanocytic conjunctival tumors. Bratisl Lek Listy 114: 446450.

53. Rodríguez-Ares $T$, Touriño R, De Rojas V, Becerra E, Capeans C (2003) Topical Mitomycin C in the Treatment of Pigmented Conjunctival Lesions. Cornea 22: 114-117.

54. Balcı M, Yağcı R, Güler E, Haltaş H, Duman R, et al. (2015) Corneal melanosis successfully treated using topical mitomycin-C and alcohol corneal epitheliectomy: A 3-year follow-up case report. Arq Bras Oftalmol 78: 255-256.

55. Shields CL, Shields JA, Armstrong T (2001) Management of conjunctival and corneal melanoma with surgical excision, amniotic membrane allograft, and topical chemotherapy. Am J Ophthalmol 132: 576-578.

56. Rozenman Y, Frucht-Pery J (2000) Treatment of Conjunctival Intraepithelial Neoplasia with Topical Drops of Mitomycin C. Cornea 19: 1-6.

57. Damato B, Coupland S (2009) An audit of conjunctival melanoma treatment in Liverpool. Eye 23: 801-809.

58. Finger PT, Czechonska G, Liarikos S (1998) Topical mitomycin $\mathrm{C}$ chemotherapy for conjunctival melanoma and PAM with atypia. Br J Ophthalmol 82: 476-479.

59. Birkholz ES, Goins KM, Sutphin JE, Kitzmann AS, Wagoner MD (2011) Treatment of ocular surface squamous cell intraepithelial neoplasia with and without mitomycin C. Cornea 30: 37-41

60. Chen C, Louis D, Dodd T, Muecke J (2004) Mitomycin C as an adjunct in the treatment of localised ocular surface squamous neoplasia. $\mathrm{Br} \mathrm{J}$ Ophthalmol 88: 17-18.

61. Kurli M, Finger PT (2005) Topical mitomycin chemotherapy for conjunctival malignant melanoma and primary acquired melanosis with atypia: 12 years' experience. Graefe's Arch Clin Exp Ophthalmo 243: 1108-1114.

62. Joag MG, Sise A, Murillo JC, Sayed-Ahmed IO, Wong JR, et al. (2016) Topical 5-fluorouracil $1 \%$ as primary treatment for ocular surface squamous neoplasia. Ophthalmology 123: $1442-1448$

63. Parrozzani R, Lazzarini D, Alemany-Rubio E, Urban F, Midena E (2011) Topical 1\% 5-fluorouracil in ocular surface squamous neoplasia: A long-term safety study. $\mathrm{Br}$ J Ophthalmol 95: 355-359.

64. Venkateswaran N, Mercado C, Galor A, Karp CL (2018) Comparison of topical 5-fluorouracil and interferon alfa$2 \mathrm{~b}$ as primary treatment modalities for ocular surface squamous neoplasia. Am J Ophthalmol 199: 216-222.

65. Yeatts RP, Engelbrecht NE, Curry CD, Ford JG, Walter KA (2000) 5-Fluorouracil for the treatment of intraepithelial neoplasia of the conjunctiva and cornea. Ophthalmology 107: 2190-2195.

66. Sun Y, Hua R (2020) Long-Term Efficacy and Safety of Subconjunctival/Perilesional 5-Fluorouracil Injections for Ocular Surface Squamous Neoplasia. Drug Des Devel Ther 14: 5659-5665. 
67. Gichuhi S, Macharia E, Kabiru J, Zindamoyen AMB, Rono $\mathrm{H}$, et al. (2016) Topical fluorouracil after surgery for ocular surface squamous neoplasia in Kenya: A randomised, double-blind, placebo-controlled trial. Lancet Glob Health 4: e378-e385.

68. Esmaeli B, Koller C, Papadopoulos N, Romaguera J (2001) Interferon-induced retinopathy in asymptomatic cancer patients. Ophthalmology 108: 858-860.

69. Fraunfelder FW, Fraunfelder FT (2011) Interferon alfa-associated anterior ischemic optic neuropathy. Ophthalmology 118: $408-411$.

70. Guyer DR, Tiedeman J, Yannuzzi LA, Slakter JS, Parke D, et al. (1993) Interferon-associated retinopathy. Arch Ophthalmol 111: 350-356.

71. Hejny C, Sternberg Jr P, Lawson DH, Greiner K, Aaberg Jr TM (2001) Retinopathy associated with high-dose interferon alfa-2b therapy. Am J Ophthalmol 131: 782-787.

72. Nishiwaki H, Ogura $Y$, Miyamoto $K$, Matsuda N, Honda $Y$ (1996) Interferon alfa induces leukocyte capillary trapping in rat retinal microcirculation. Arch Ophthalmol 114: 726730.

73. Shah SU, Kaliki S, Kim HJ, Lally SE, Shields JA, et al. (2012) Topical interferon alfa-2b for management of ocular surface squamous neoplasia in 23 cases: Outcomes based on American Joint Committee on Cancer classification. Arch Ophthalmology 130: 159-164.

74. Boehm MD, Huang AJ (2004) Treatment of recurrent corneal and conjunctival intraepithelial neoplasia with topical interferon alfa 2b. Ophthalmology 111: 1755-1761.
75. Herold TR, Hintschich C (2010) Interferon a for the treatment of melanocytic conjunctival lesions. Graefes Arch Clin Exp Ophthalmol 248: 111-115.

76. Khong JJ, Muecke J (2006) Complications of mitomycin C therapy in 100 eyes with ocular surface neoplasia. $\mathrm{Br} \mathrm{J}$ Ophthalmol 90: 819-822.

77. Salomão DR, Mathers WD, Sutphin JE, Cuevas K, Folberg $R$ (1999) Cytologic changes in the conjunctiva mimicking malignancy after topical mitomycin C chemotherapy. Ophthalmology 106: 1756-1761.

78. Frucht-Pery J, Sugar J, Baum J, Sutphin JE, Pe'er J, et al. (1997) Mitomycin C treatment for conjunctivalcorneal intraepithelial neoplasia: A multicenter experience. Ophthalmology 104: 2085-2093.

79. Sacu S, Ségur-Eltz N, Horvat R, Lukas JR, Zehetmayer M (2003) Intumescent cataract after topical mitomycin-C for conjunctival malignant melanoma. Am J Ophthalmol 136: 375-377.

80. Ditta LC, Shildkrot Y, Wilson MW (2011) Outcomes in 15 patients with conjunctival melanoma treated with adjuvant topical mitomycin C: complications and recurrences. Ophthalmology 118: 1754-1759.

81. Simsek T, Firat P, Çtrk M, Ozdamar Y, Elgin U (2010) Shortterm effects of subconjunctival injections of 5-fluorouracil on conjunctival epithelium. Cornea 29: 727-731. 